\title{
MUSCARINIC RECEPTORS: EVIDENCE FOR A NONUNIFORM DISTRIBUTION IN TRACHEAL SMOOTH MUSCLE AND EXOCRINE GLANDS ${ }^{1}$
}

\author{
C. B. BASBAUM, ${ }^{2}$ M. A. GRILlo, AND J. H. WIDDICOMBE \\ Cardiovascular Research Institute and Departments of Anatomy and Physiology, University of California, San Francisco, \\ San Francisco, California 94143
}

Received May 23, 1983; Revised September 7, 1983; Accepted October 4, 1983

\begin{abstract}
Muscarinic receptor distribution in smooth muscle, exocrine glands, and epithelium of the ferret trachea was determined using $\left[{ }^{3} \mathrm{H}\right]$ propylbenzilylcholine mustard $\left(\left[{ }^{3} \mathrm{H}\right] \operatorname{PrBCM}\right)$ binding and autoradiography. Specific, atropine-sensitive $\left[{ }^{3} \mathrm{H}\right] \operatorname{PrBCM}$ binding was quantified autoradiographically in the trachealis muscle (approximately 21 binding sites $/ \mu \mathrm{m}^{2}$ ), surface epithelium (approximately 6 binding sites $/ \mu \mathrm{m}^{2}$ ), and submucosal glands (approximately 5 binding sites $/ \mu \mathrm{m}^{2}$ ). Serous and mucous cells in the glands did not differ in receptor density. Binding sites on gland and epithelial cells were associated with basolateral membranes. In the trachealis muscle, a gradient in receptor density was observed, with outer layers of muscle containing 3 to 10 times more receptors per unit area than inner layers. Receptor distribution in both glands and muscle paralleled the distribution of cholinergic axons. However, at the light microscope level, there was no evidence for the presence of receptor "hot spots" related to the position of individual axons. The parallelism in the distribution of axons and receptors suggests the possibility of neural control of the genesis and/or maintenance of receptor distribution in these tissues.
\end{abstract}

Two major classes of cholinergic receptor have been described, nicotinic and muscarinic. These are defined according to their differential affinities for the agonists nicotine and muscarine and the antagonists curare and atropine (Dale, 1914). In the periphery, nicotinic receptors are found in high concentration at neuromuscular junctions of skeletal muscle and in autonomic ganglia; muscarinic receptors are found in high concentration at autonomic neuroeffector junctions and in autonomic ganglia.

The spatial distribution of nicotinic receptors in the postsynaptic membrane has been well characterized. In both skeletal muscle and autonomic ganglion cells, receptors occur at high density immediately apposed to the axon terminal but are sparse elsewhere on the cell surface

\footnotetext{
${ }^{1}$ This work was supported by National Heart, Lung, and Blood Institute Program Grant HL-24136, and by a grant from the Strobel Foundation of the American Lung Association of San Francisco. We thank Dr. Jay A. Nadel for his interest and support during the course of these studies, and Dr. Michael Kuhar for kindly providing us with $\left[{ }^{3} \mathrm{H}\right] \operatorname{PrBCM}$ to begin these studies. We also thank Leona Lauricella, Iris Ueki, and Ella Highland for technical assistance, and Beth Cost and Patty Snell for preparing the manuscript.

${ }^{2}$ To whom correspondence should be addressed, at Cardiovascular Research Institute, 1315-M, University of California, San Francisco, San Francisco, CA 94143.
}

(Fertuck and Salpeter, 1974; Lentz et al., 1977; Marshall 1981). The spatial distribution of muscarinic receptors in the postsynaptic membrane is less well characterized. That it differs from the distribution of nicotinic receptors, however, is indicated by studies of receptor distribution in the frog heart (Hartzell, 1980). There, in contrast to findings in skeletal muscle, no evidence was found for "hot spots" on individual cardiac muscle fibers apposed to individual axons.

The topographic relationship of receptors to axons has yet to be studied in smooth muscle. Autoradiographic studies of radioligand binding patterns offer a direct and quantifiable method for determining receptor distribution. Therefore, in the present study, we used a tritiated covalently binding muscarinic antagonist and autoradiographic methods to study the distribution of muscarinic receptors in the trachea. The trachea was chosen for three important reasons. First, the trachealis muscle contains a high concentration of muscarinic receptors (Murlas et al., 1982). Second, the regulation of ion transport by the tracheal epithelium involves muscarinic receptors (Marin et al., 1976) whose location is unknown. Finally, the regulation of secretion from the mixed (seromucous) tracheal glands involves activation of muscarinic receptors (Florey et al., 1932; Sturgess and Reid, 1972; Chakrin et al., 1973; Boat and Kleinerman, 1975; 
Gallagher et al., 1975; Davis et al., 1979; Ueki et al., 1979, 1980 ) whose location is incompletely known (Basbaum et al., 1981; Tom-Moy et al., 1983).

Results of the present study provide estimates of muscarinic receptor density for each major cell type and reveal a nonuniformity in receptor distribution within individual gland cells and among regions of the trachealis muscle.

To examine the topographic relationship between muscarinic receptors and cholinergic axons, the distribution of cholinergic axons was mapped by electron microscopy and found to parallel the distribution of muscarinic receptors.

\section{Materials and Methods}

General. Ferrets (Mustela furo), weighing about $1 \mathrm{~kg}$, were anesthetized with sodium pentobarbital $(30 \mathrm{mg} / \mathrm{kg}$, i.p.) and their tracheas were removed. For autoradiography, excess connective tissue was dissected off, and the trachea was divided into 12 transverse segments, each about $1 \mathrm{~cm}$ in length. For the binding assays, the trachealis muscle or surface epithelium was dissected off and divided into approximately 12 pieces. Binding studies were also done on pieces of trachea from which the trachealis muscle had been removed. Samples were equilibrated ( $30 \mathrm{~min}$ ) in oxygenated Krebs-Henseleit solution of the following composition $(\mathrm{mM}): \mathrm{Na}^{+}, 143.9 ; \mathrm{K}^{+}, 5.6$; $\mathrm{Ca}^{2+}, 1.9 ; \mathrm{Mg}^{2+}, 1.2 ; \mathrm{Cl}^{-}, 123.2 ; \mathrm{HCO}_{3}^{-}, 25.0$; gluconate ${ }^{-}$, $3.8 ; \mathrm{H}_{2} \mathrm{PO}_{4}^{-}, 1.3 ; \mathrm{SO}_{4}^{2-}, 1.2 ;$ glucose, 5.6. This solution was maintained at $\mathrm{pH} 7.4$ by bubbling with $95 \% \mathrm{O}_{2}$ and $5 \%$ $\mathrm{CO}_{2}$.

$\left[{ }^{3} \mathrm{H}\right]$ Propylbenzilylcholine mustard binding. $\left[{ }^{3} \mathrm{H}\right]$ Propylbenzilylcholine mustard $\left.\left({ }^{3} \mathrm{H}\right] \mathrm{PrBCM}\right)(15.0$ or 42.0 $\mathrm{Ci} / \mathrm{mmol}$ ) was obtained from Amersham Radiochemicals. The concentration of the stock solution was $2.43 \times 10^{-5}$ M. Immediately prior to use, this was diluted with ungassed (therefore alkaline, $\mathrm{pH}$ 7.6) Krebs-Henseleit solution to give a working stock solution with a PrBCM concentation of $10^{-6} \mathrm{M}$. This was kept for $1 \mathrm{hr}$ at room temperature to allow cyclization to the pharmacologically active aziridinium ion (Gill and Rang, 1966; Burgen et al., 1974). Aliquots of this working stock solution were then added to the incubation medium to produce a final concentration of $5 \times 10^{-9} \mathrm{M}$ (except where indicated). All incubations were performed at $30^{\circ} \mathrm{C}$, to minimize hydrolysis of the PrBCM (Gill and Rang, 1966; Burgen et al., 1974).

To determine the washing period needed for removal of extracellular PrBCM, tissues were loaded with $\left[{ }^{3} \mathrm{H}\right]$ PrBCM for $80 \mathrm{~min}$ and then passed through a series of scintillation vials containing $3 \mathrm{ml}$ of oxygenated nonradioactive medium at 2 -min intervals. The counts in the vials and the counts in the muscle after removal from the last vial were then determined, and the efflux of $\left[{ }^{3} \mathrm{H}\right]$ $\mathrm{PrBCM}$ was calculated. Similar experiments were performed with $\left[{ }^{3} \mathrm{H}\right]$ inulin (New England Nuclear).

Following incubation and washout of extracellular tracer, the tissues were either dried in a vacuum oven at $60^{\circ} \mathrm{C}$ overnight or were fixed and dehydrated by passage through methanols and propylene oxide as described below, under "Electron microsocopy." The vacuum-dried, unfixed tissues or the methanol-dehydrated, fixed tissues were weighed on a Mettler MS 1 balance to the nearest $0.01 \mathrm{mg}$. They were then moistened with $20 \mu \mathrm{l}$ of distilled water and $200 \mu \mathrm{l}$ of NCS tissue solubilizer (Amersham Radiochemicals) and dissolved overnight at $50^{\circ} \mathrm{C}$. Organic counting solution (Amersham Radiochemicals) was added and the tissues were counted on a Beckman LS 7500 beta counter. Differences in counting efficiency were corrected for, using a standard quench correction curve. Aliquots $(20 \mu \mathrm{l})$ of the incubation media were taken and treated in the same way as the tissue samples. Binding was expressed initially as microliters per milligram dry weight $\left(=\mathrm{cpm} \cdot \mathrm{mg}^{-1}\right.$ dry weight $/ \mathrm{cpm} \cdot \mu \mathrm{l}^{-1}$ incubation solution). Using Avogadro's number and the known concentration of $\operatorname{PrBCM}\left(5 \times 10^{-9} \mathrm{M}\right)$, this unit was then converted to molecules of $\mathrm{PrBCM} / \mathrm{mg}$ dry weight.

Measurement of extracellular space and dry weight:wet weight ratio. Attempts were made to measure the dissected muscle's extracellular space with $\left[{ }^{3} \mathrm{H}\right]$ mannitol (New England Nuclear), $\left[{ }^{14} \mathrm{C}\right]$ sucrose (Amersham), or $\left[{ }^{3} \mathrm{H}\right]$ methoxyinulin (New England Nuclear). The tissue and solution samples were treated exactly as in the $\left[{ }^{3} \mathrm{H}\right]$ PrBCM experiments. The extracellular spaces were expressed as a fraction of total tissue weight $(\mu \mathrm{l} / \mathrm{mg}$ wet weight), where $\mu \mathrm{l} / \mathrm{mg}$ wet weight $=\mathrm{cpm} \cdot \mathrm{mg}^{-1} \cdot$ wet weight $/ \mathrm{cpm} \cdot \mu \mathrm{l}^{-1}$ of incubation medium. Exposure times varied from 20 to $60 \mathrm{~min}$.

In all experiments, the extracellular markers showed penetration into the muscle with increasing incubation periods. We ascribe this to membrane leakiness caused by dissection damage. Extrapolation of the binding points to zero time suggested that the true extracellular space was $0.45 \mu \mathrm{l} \cdot \mathrm{mg}^{-1}$ wet weight. Similar results were obtained with the different extracellular tracers.

When determining the wet weight:dry weight ratio of the muscle, tissues were removed from Krebs solution, blotted lightly on Whatman no. 1 filter paper, and weighed on a Mettler MS1 balance to the nearest 0.01 $\mathrm{mg}$. This gave an estimate of the wet weight. Dry weights were determined as described above.

Autoradiography. Transverse segments of ferret tracheas (approximately $1 \mathrm{~cm}$ in length) were incubated at $30^{\circ} \mathrm{C}$ in $\left[{ }^{3} \mathrm{H}\right] \mathrm{PrBCM}\left(5 \times 10^{-9} \mathrm{M}\right)$ with or without atropine $\left(10^{-4} \mathrm{M}\right)$. After $80 \mathrm{~min}$ of incubation, samples were rinsed for $45 \mathrm{~min}$ in Krebs-Henseleit solution to remove unbound ligand and fixed in one of two fixatives. Fixative A consisted of $10 \%$ paraformaldehyde in $1.5 \mathrm{M}$ cacodylate buffer, $\mathrm{pH}$ 7.4. Fixative $\mathrm{B}$ consisted of $1 \%$ acrolein and $2.3 \%$ glutaraldehyde in $0.1 \mathrm{M}$ cacodylate buffer, with 5 $\mathrm{mM} \mathrm{CaCl}, \mathrm{pH}$ 7.4. Samples were kept in these fixatives for approximately $18 \mathrm{hr}\left(4^{\circ} \mathrm{C}\right)$. They were then dehydrated in methanols, passed through propylene oxide or $\alpha$-terpineol, and vacuum embedded in Araldite, glycolmethacrylate, or paraffin. ${ }^{3}$ Araldite sections $(2 \mu \mathrm{m})$ were cut using a Porter-Blum Mt-2B ultramicrotome. Glycol-

\footnotetext{
${ }^{3}$ These methods are modified from those used in the central nervous system by Rotter et al. (1979) and Kuhar et al. (1981). Principal differences between the techniques are: (1) use of tissue pieces rather than cryostat or tissue chopper sections for incubation with $\left[{ }^{3} \mathrm{H}\right]$ PrBCM; (2) use of living tissue rather than tissue frozen or prefixed with $0.1 \%$ glutaraldehyde; and (3) use of significantly longer $\left[{ }^{3} \mathrm{H}\right]$ PrBCM incubation periods ( 80 versus $15 \mathrm{~min}$ ).
} 
methacrylate sections $(2.5 \mu \mathrm{m})$ were cut using a JB-4 microtome, and paraffin sections $(10 \mu \mathrm{m})$ were cut using a rotary microtome.

All sections were mounted on glass slides and dipped in liquid emulsion (Kodak NTB-2) diluted 1:1 with distilled water. Slides were allowed to dry overnight and then were placed in light-proof boxes and stored at $4^{\circ} \mathrm{C}$ for 1 to 8 months prior to development.

Slides were developed in $\mathrm{D}-19$ for $3 \min \left(16^{\circ} \mathrm{C}\right)$, rinsed in distilled water for $1 \mathrm{~min}\left(16^{\circ}\right)$, and fixed for $4 \mathrm{~min}$ $\left(16^{\circ} \mathrm{C}\right)$ in Kodak Rapidfix without hardener. They were then rinsed for $20 \mathrm{~min}$ in distilled water and lightly stained. Paraffin sections were stained with cresyl violet $(2 \%)$; Araldite and glycolmethacrylate sections were stained with toluidine or methylene blue. Sections were then dehydrated in ethanols, cleared in xylene, and covered with Permount and glass coverslips.

Morphometry. Quantification of autoradiographic silver grains over the glands was done by tracing gland profiles and drawing in silver grains directly from histological slides by means of a drawing tube attached to a standard light microscope. The final enlargement of the image was $\times 1250$. The areas of gland profiles were computed using a digitizer interfaced with a Hewlett-Packard computer $(9815 \mathrm{~A})$. The number of silver grains per square micrometer of tissue section was then calculated. For the muscle and epithelium, most grain counts were made directly from microscope slides, using an ocular grid with a $\times 100$ objective. The final magnification at which grain counts were made was $\times 1000$. The number of grains counted for each cell type is shown in the legend for Table III. In all cases, the number of grains counted exceeded the number required to give a coefficient of variation of 0.05 or less (Rogers, 1979, p. 417).

To examine regional differences within the muscle, we made photographic prints $(\times 2000)$ showing the entire thickness of the muscle. Because of the parallel orientation of the cells, it was possible to lay a transparent grid over each photograph which divided the muscle into 5$\mu \mathrm{m}$ zones, starting from the adventitial surface. The number of grains in each zone was divided by the area of the zone to give regional grain densities.

Because our autoradiographs indicated that the receptors occurred chiefly on cell surfaces (see below), we calculated the area of cell surface contained in each unit area of tissue section. To do this, we needed both the volume of tissue per unit area of section and the surface to volume relationship for each cell type. Volume of tissue was obtained by multiplying the sectional area (e.g., per gland profile) by the section thickness. Surface to volume ratios were obtained by tracing cell boundaries on low magnification $(\times 3600)$ electron micrographs using a digitizer and computer programmed to generate perimeter and area measurements. The ratio of perimeter to area is the same as the ratio of surface to volume. Average values were obtained from measurements made on 20 cells of each type (serous, mucous, smooth muscle, and epithelium). Smooth muscle caveolae membrane was excluded in making these measurements. Tissue volume $\times$ surface:volume ratio gave surface area for each profile measured. Grain counts were then expressed with reference to unit area of cell surface. These data were nor- malized for exposure time and specific activity of the radioligand. Using the following formula (Lane et al., 1977), grain counts were used to calculate receptor density for each cell type:

$$
R=(g d / t) \times A /(S C)
$$

where $R$ is the number of receptors per unit area of cell surface, $g$ is the number of developed "specific" grains for the same area, $d$ is the number of decays required to give one developed grain, $t$ is the exposure time in days, $A$ is Avogadro's number $\left(6.025 \times 10^{20}\right.$ molecules $\left./ \mathrm{mmol}\right)$, $S$ is specific activity, and $C$ is the number of decays/day. $\mathrm{Ci}, 3.2 \times 10^{9}$.

Electron microscopy. Tracheal rings removed from anesthetized ferrets were placed in oxygenated Krebs-Henseleit solution containing atropine $\left(10^{-4} \mathrm{M}\right)$ for $30 \mathrm{~min}$ to relax the trachealis muscle. They were then fixed for $18 \mathrm{hr}$ at $4^{\circ} \mathrm{C}$ in $0.08 \mathrm{M}$ cacodylate buffer ( $\left.\mathrm{pH} 7.4\right)$ containing $2.5 \%$ glutaraldehyde, $5 \mathrm{~mm} \mathrm{CaCl} 2+1 \%$ sucrose. Following this, the rings were trimmed and placed in osmium tetroxide $(1.5 \%$ in $30 \mathrm{~mm}$ veronal acetate, $\mathrm{pH}$ 7.4) for $24 \mathrm{hr}$. Specimens were then dehydrated in ethanols, passed through propylene oxide, and embedded in Araldite. Sections having a silver interference color were cut with a diamond knife on a Sorvall Porter-Blum MT2B ultramicrotome, placed on paralodion-coated mesh or Formvar-coated slot grids, stained with 5\% uranyl acetate and $0.4 \%$ lead citrate, and viewed at $80 \mathrm{kV}$ in a Zeiss EM-10 electron microscope. Montages were made through the full thickness of the trachealis muscle, using photographs at a final magnification of $\times 2,000$ to map the distribution of cholinergic axons. The position of each axon was marked on the montages by placing grids back in the microscope and viewing the sections at $X$ 20,000 . Sections were scanned systematically in overlapping vertical columns. Data were expressed as the number of axons per square micrometer associated with each $5-\mu \mathrm{m}$ zone internal and external to the outer muscle surface.

\section{Results}

\section{Selection of incubation conditions for autoradiography using $\left[{ }^{3} \mathrm{H}\right] \operatorname{PrBCM}$}

Binding and washout from intact muscle pieces. Figure 1 shows the washout of $\left[{ }^{3} \mathrm{H}\right] \operatorname{PrBCM}\left(5 \times 10^{-9} \mathrm{M}\right)$ and inulin from trachealis muscle pieces following an $80-\mathrm{min}$ incubation period. It is clear that after $45 \mathrm{~min}$, inulin is more or less completely washed out from the tissue, whereas $\left[{ }^{3} \mathrm{H}\right] \mathrm{PrBCM}$ levels remain stable at about $50 \%$ of the total initial counts. Therefore, in all subsequent experiments we rinsed tissues for $45 \mathrm{~min}$ to remove extracellular and loosely bound $\left[{ }^{3} \mathrm{H}\right] \mathrm{PrBCM}$.

Binding in the presence of atropine $\left(10^{-4} \mathrm{M}\right)$ was approximately linear with time (Fig. 2), as reported previously for other tissues (e.g., Burgen et al., 1974). After $60 \mathrm{~min}$, however, the difference in binding between atropine-containing and atropine-free media was constant (Fig. 2) and remained constant for up to $4 \mathrm{hr}$ after

\footnotetext{
4 "Specific" grains $=\left(\right.$ total grains $\left./ \mu \mathrm{m}^{2}\right)-($ nonspecific + background grains $/ \mu \mathrm{m}^{2}$ ).
} 


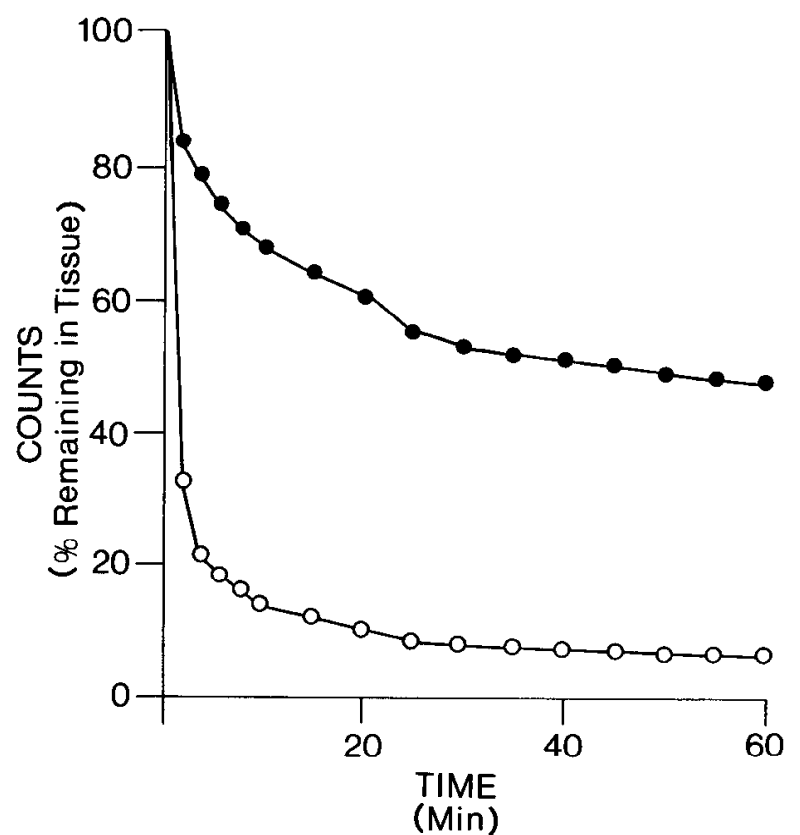

Figure 1. Washout of $\left[{ }^{3} \mathrm{H}\right] \operatorname{PrBCM}(\Theta)$ or $\left[{ }^{3} \mathrm{H}\right]$ inulin $(\mathrm{O})$ from trachealis muscle. Each curve is a single efflux for muscle pieces from the same dog.

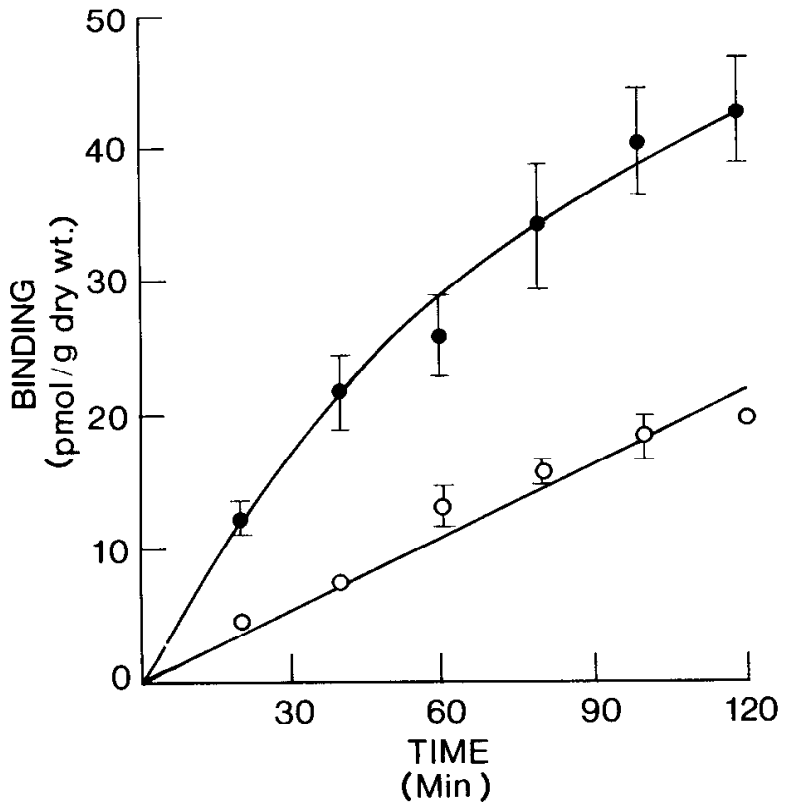

Figure 2. Binding of $\left[{ }^{3} \mathrm{H}\right] \operatorname{PrBCM}$ by trachealis muscle. atropine; $O,+10^{-4} \mathrm{M}$ atropine. Means \pm SEM of three to five tissues fixed in paraformaldehyde and dehydrated prior to counting.

addition of ligand (data not shown). In other words, nonspecific binding increased with time, but the specific, atropine-sensitive binding of $\left[{ }^{3} \mathrm{H}\right] \operatorname{PrBCM}$ reached equilibrium after about $60 \mathrm{~min}$. Therefore, to ensure equilibrium binding we used 80 -min incubations in all subsequent experiments.

Binding by tracheal rings with muscle removed. Total binding of $\left[{ }^{3} \mathrm{H}\right] \operatorname{PrBCM}\left(5 \times 10^{-9} \mathrm{M}\right)$ by tracheal rings was low (Fig. 3). Both total and nonspecific binding increased linearly with time, showing poor separation

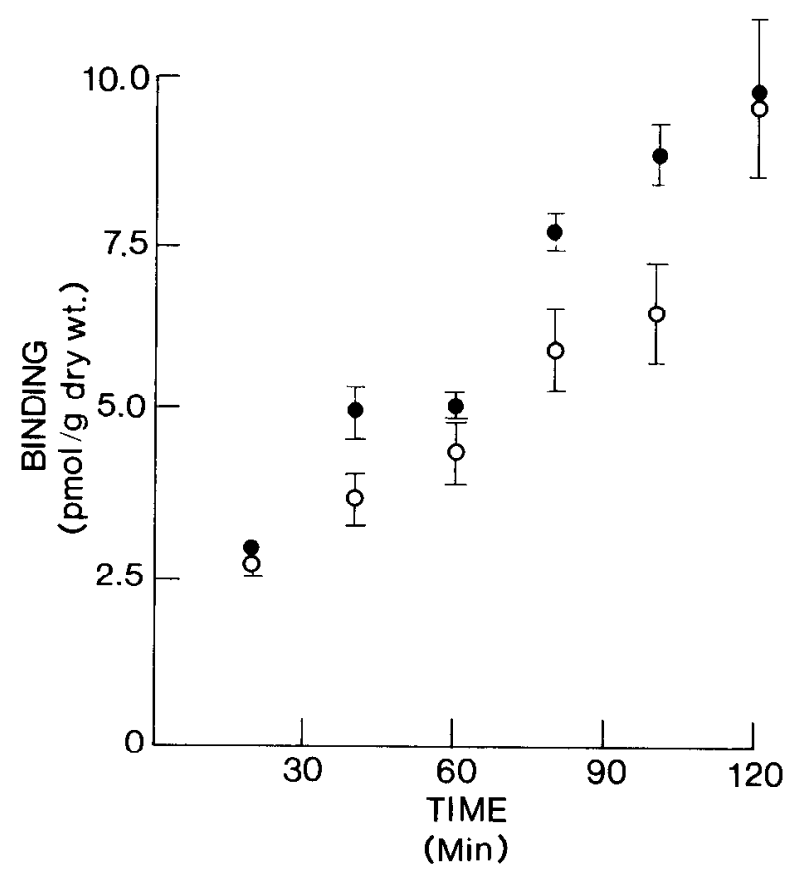

Figure 3. Binding of $\left[{ }^{3} \mathrm{H}\right] \mathrm{PrBCM}$ by muscle-free tracheal rings, with (O) or without (O) $10^{-4} \mathrm{M}$ atropine. Values are means $\pm \mathrm{SEM}$ of five tissues.

\section{TABLE I}

Effects of fixation on retention of radioactivity

"Total" binding is the binding in the absence and "nonspecific" binding is the binding in the presence of $10^{-4} \mathrm{M}$ atropine. "Specific" binding is the difference between the two. Binding is in $\mathrm{pmol} \cdot \mathrm{gm}^{-1}$ dry weight. Values are means \pm SEM of five to six muscles.

\begin{tabular}{lrccc}
\hline & Total & Nonspecific & Specific & Total \\
\hline Fresh tissue & $107.2 \pm 8.2$ & $77.1 \pm 8.8$ & $30.1 \pm 12.0$ & 1.39 \\
Formaldehyde-fixed & $44.4 \pm 9.5$ & $17.1 \pm 3.0$ & $27.3 \pm 10.0$ & 2.60 \\
$\begin{array}{l}\text { tissue } \\
\begin{array}{l}\text { Glutaraldehyde-fixed } \\
\text { tissue }\end{array}\end{array}$ & $38.7 \pm 5.1$ & $20.5 \pm 2.2$ & $18.2 \pm 5.6$ & 1.89 \\
\hline
\end{tabular}

between total and nonspecific binding. We attribute this to a high degree of nonspecific binding to cartilage and connective tissue in intact tracheal rings.

\section{Effects of fixation and dehydration on binding of $\left[{ }^{3} \mathrm{H}\right]$ $\operatorname{PrBCM}$}

Table I compares the levels of tissue $\left[{ }^{3} \mathrm{H}\right] \mathrm{PrBCM}$ after 80 min of incubation and 45 min washing in media with and without atropine $\left(10^{-4} \mathrm{M}\right)$. Data are shown for tissues both desiccated and counted immediately after washing ("fresh") and tissues passed through fixative and alcohols before counting.

It is clear that fixation and alcohol dehydration greatly reduce nonspecific binding and optimize the ratio between specific and nonspecific binding. The difference in binding in the presence and absence of atropine for fresh tissues ( $30.1 \mathrm{pmol} / \mathrm{gm}$ ) is not significantly different from the difference for paraformaldehyde-fixed and dehydrated tissues $(27.3 \mathrm{pmol} / \mathrm{gm})$, indicating that little or no specifically bound ligand is lost during fixation and dehydration. 


\section{Specificity of $\left[{ }^{3} \mathrm{H}\right] \operatorname{PrBCM}$ binding}

$\left[{ }^{3} \mathrm{H}\right] \mathrm{PrBCM}$ binding was compared after $80 \mathrm{~min}$ incubation alone and in the presence of the nicotinic antagonists curare and hexamethonium and the muscarinic agonist methacholine and antagonist atropine (all at $10^{-4}$ M). Neither nicotinic agent significantly reduced $\left[{ }^{3} \mathrm{H}\right]$ PrBCM binding, whereas both methacholine and atropine reduced binding by approximately $50 \%$ (Table II), establishing the specificity of interaction of $\left[{ }^{3} \mathrm{H}\right] \operatorname{PrBCM}$ with muscarinic receptors.

\section{Estimation of receptor density in trachealis muscle by $\left[{ }^{3} \mathrm{H}\right] \operatorname{PrBCM}$ binding}

Using a specific $\left[{ }^{3} \mathrm{H}\right] \operatorname{PrBCM}$-binding value of 25.0 $\mathrm{pmol} / \mathrm{gm}$ dry weight (see Table I), and using the dry weight to wet weight ratio of $0.176 \pm 0.005(n=25)$, and assuming an extracellular space of $0.45 \mu \mathrm{l} / \mathrm{mg}(n=4)$ (see "Materials and Methods"), then binding can be expressed as $(25.0 \times 0.176) /(1-0.45)=8.0 \mathrm{pmol} / \mathrm{gm}$ of wet cells. Taking the surface to volume ratio of smooth muscle cells to be $1.4 \mu \mathrm{m}^{2} / \mu \mathrm{m}^{3}$ (see "Materials and Methods"), assuming a density of $1.06 \mathrm{mg} / \mu \mathrm{l}$, and using Avogadro's number, then $8.0 \mathrm{pmol} / \mathrm{gm}$ of wet cells converts to 3.6 receptors $/ \mu \mathrm{m}^{2}$ cell membrane.

\section{Electron microscopy}

Gland morphology and innervation. The morphology of ferret tracheal glands has been described previously (Basbaum et al., 1981). The glands consist of both serous and mucous cells occupying the submucosal region of the anterior portion of the trachea. Individual serous cells are approximately $5 \mu \mathrm{m}$ wide and $10 \mu \mathrm{m}$ in length, and mucous cells are approximately $8 \mu \mathrm{m}$ wide and $12 \mu \mathrm{m}$ in length. Both cholinergic and adrenergic axons surround gland acini (Fig. 4), the majority occurring several micrometers from the nearest gland acinus, consistent with the pattern of innervation seen in cat tracheal glands (Murlas et al., 1980). Cholinergic varicosities were identified by the presence of small ( 40 to $60 \mathrm{~nm}$ ) agranular synaptic vesicles, and adrenergic varicosities were identified by the presence of small $(40$ to $50 \mathrm{~nm})$ dense-cored vesicles.

Epithelial morphology and innervation. The structure of tracheal epithelium has been described extensively (for review, see Breeze and Wheeldon, 1977). Histochemical studies have been performed on ferret tracheal epithelium (Jacob and Poddar, 1982). Cholinergic axons can

\section{TABLE II}

Effects of cholinergic agents on $\left[{ }^{3} \mathrm{H}\right] \mathrm{Pr} B \mathrm{CM}$ binding

In these experiments, the concentration of $\left[{ }^{3} \mathrm{H}\right] \mathrm{PrBCM}$ was $10^{-9} \mathrm{M}$. $p$ shows probability of significant difference from control as determined by the Student's $t$ test. The concentration of all cholinergic agents was $10^{-4} \mathrm{M}$.

\begin{tabular}{lccc}
\hline & $\begin{array}{c}\text { Binding } \\
\text { (pmol/gm dry wt.) }\end{array}$ & $n$ & $p$ \\
\hline Control & $10.57 \pm 1.02$ & 7 & \\
Hexamethonium & $11.71 \pm 0.89$ & 8 & $\mathrm{NS}^{a}$ \\
Curare & $7.82 \pm 0.87$ & 8 & $\mathrm{NS}$ \\
Methacholine & $5.19 \pm 0.19$ & 7 & $<0.0005$ \\
Atropine & $4.30 \pm 0.52$ & 7 & $<0.0005$ \\
\hline
\end{tabular}

${ }^{a}$ NS, not significant. be observed in the lamina propria underlying the epithelium.

Muscle morphology and innervation. The trachealis muscle of the ferret has not previously been described. It is approximately $40 \mu \mathrm{m}$ thick (range 20 to $55 \mu \mathrm{m}$ ), composed of 10 to 15 layers of smooth muscle cells. The cells are approximately $200 \mu \mathrm{m}$ in length and approximately $5 \mu \mathrm{m}$ in diameter in the nuclear region, with tapered ends. Gap junctions connecting adjacent muscle cells are common. The muscle is innervated by a plexus of adrenergic and cholinergic axons. Large axon bundles are present in the adventitial connective tissue, becoming smaller in the immediate vicinity of the muscle (Fig. 5). Interfascicular axons occur singly or in groups of two to three. No intrafascicular axons were observed.

Morphometric analysis of the distribution of cholinergic axons revealed that a majority $(94 \%)$ of axons occurred within $5 \mu \mathrm{m}$ of the adventitial surface (Fig. 6).

\section{Autoradiography}

General. Autoradiography of tissues incubated with atropine plus $\left[{ }^{3} \mathrm{H}\right] \mathrm{PrBCM}$ showed negligible autoradiographic labeling. In tissues incubated without atropine, prominent labeling occurred over trachealis muscle, submucosal glands, and surface epithelium. Simple observation revealed muscle to be the most densely labeled of the three sites. Early experiments showed that no labeling was seen over the glands unless the surfacc epithelium was removed or access of $\left[{ }^{3} \mathrm{H}\right] \mathrm{PrBCM}$ provided thorough proximity to the cut edge of a tissue block.

Muscle. Grain density over Araldite-embedded muscle incubated without atropine was $9.08 \pm 0.65$ (mean number of grains $/ 100-\mu \mathrm{m}^{2}$ tissue section $\pm \mathrm{SEM} ; n=4$ sections from two muscle pieces). In the presence of atropine, the grain density was $0.73 \pm 0.38(n=4$ sections from two muscle pieces). The ratio of total to nonspecific binding was 12.44. Conversion of these figures as described under "Materials and Methods" gave approximately 21 receptor sites $/ \mu \mathrm{m}^{2}$ cell surface. These and all subsequent figures derived from grain counts are presented in Table III. There was no indication of clustering of receptors (hot spots) within the muscle (Fig. 7). However, a gradient in the regional distribution of receptors in trachealis muscle was observed (Fig. 7 to 9 ). Receptor sites were 3 to 10 times more numerous on the adventitial than on the mucosal surface of the muscle. It was difficult to determine whether the gradient was real or related to poor penetration of $\left[{ }^{3} \mathrm{H}\right] \mathrm{PrBCM}$. To investigate this, we prepared several muscles in which the epithelium was stripped from the trachea prior to incubation with $\left[{ }^{3} \mathrm{H}\right]$ PrBCM to provide free access to the muscle from both surfaces. Neither autoradiography (Fig. 10 and 11) nor binding assays revealed additional radioactivity entering the muscle despite this procedure, thus supporting the existence of a true gradient. Muscle with intact epithelium bound $5.70 \pm 0.55 \mathrm{pmol} \cdot \mathrm{gm}^{-1}$ dry weight $\left[{ }^{3} \mathrm{H}\right]$ PrBCM. With epithelium stripped, the value was $8.16 \pm$ $1.55 \mathrm{pmol} \cdot \mathrm{gm}^{-1}$ dry weight. Values are means \pm SEM for 12 muscle pieces. Means were not significantly different $(p>0.10)$.

Epithelium. Grain density over nonatropinized Aral- 


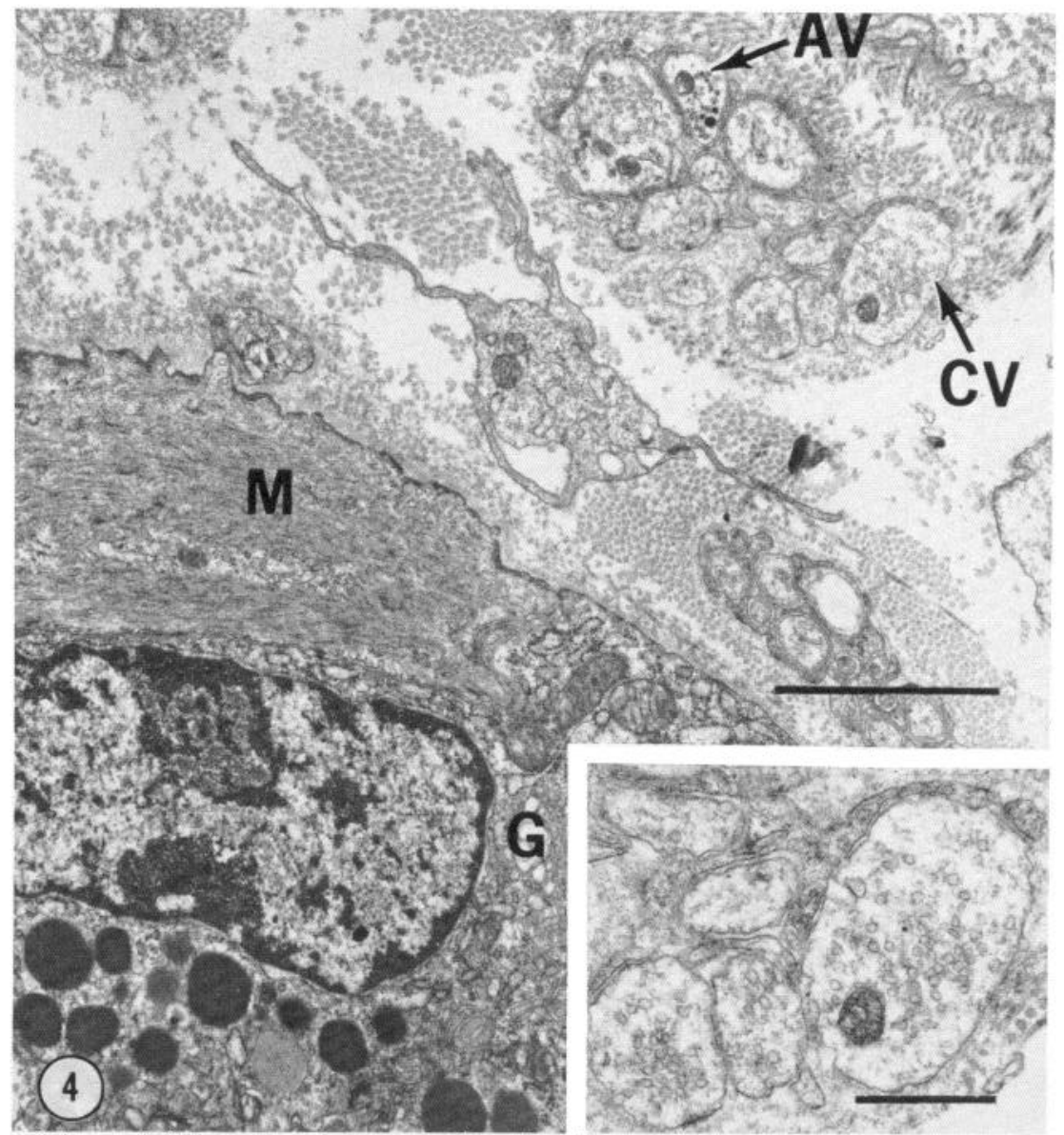

Figure 4. Electron micrograph showing the usual relationship between gland cells $(G)$ and autonomic axons. $A V$, adrenergic varicosity; $C V$, cholinergic varicosity; $M$, myoepithelial cell. Scale bar $=4 \mu \mathrm{m}$. Inset, Cholinergic varicosities. Scale bar $=1 \mu \mathrm{m}$.

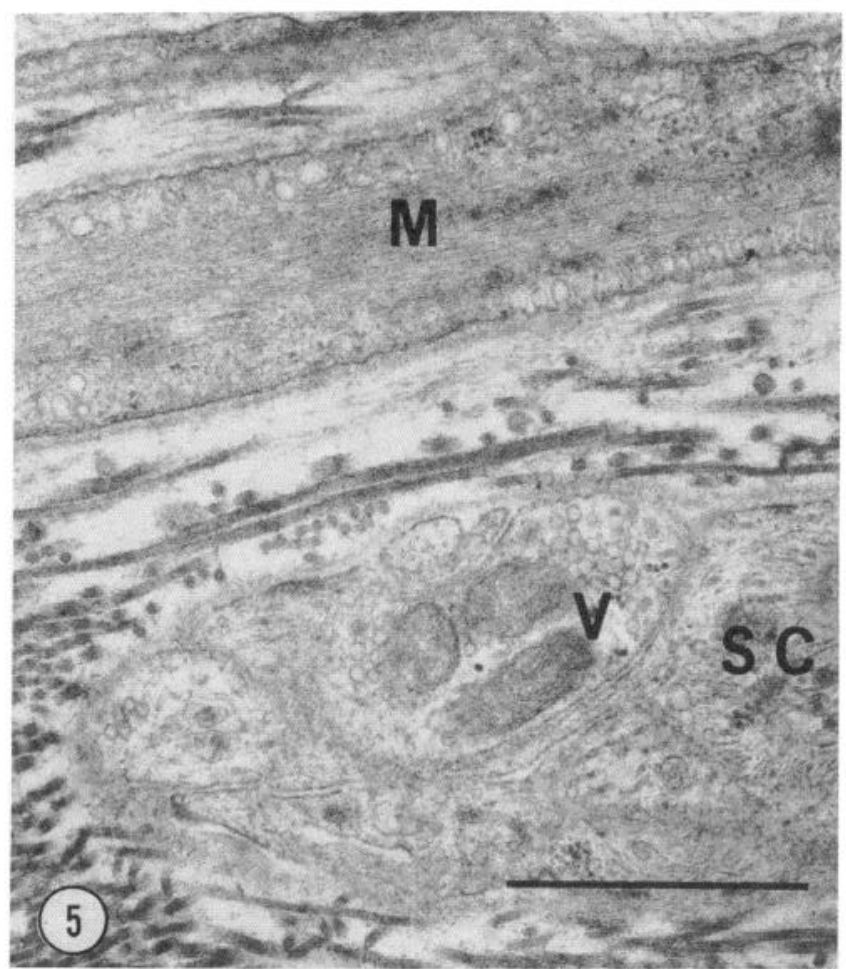

dite-embedded tracheal epithelium was $2.27 \pm 0.08$ grains $/ 100 \mu \mathrm{m}^{2}$. In the presence of atropine, there were $0.13 \pm 0.13$ grains $/ 100 \mu \mathrm{m}^{2}$ (both mean \pm SEM; $n=4$ sections from two pieces of tissue). The ratio of total to nonspecific binding was 17.46. The number of receptors per square micrometer of cell membrane was approximately 6 . Silver grains were concentrated basolaterally, with apical membranes generally free of grains (Figs. 12 and 13). A binding assay done on isolated epithelial strips showed modest atropine-sensitive binding (Fig. 14).

Glands. Grain density in the submucosal glands did not differ greatly from serous to mucous acini. In the absence of atropine, grain density was $3.44 \pm 0.15$ grains/ $100-\mu \mathrm{m}^{2}$ tissue section (mean $\pm \mathrm{SEM} ; n=4$ sections from two pieces of tissue) over serous and $2.71 \pm 0.25$ over mucous acini. Corresponding figures in the presence of atropine were $0.38 \pm 0.05$ and $0.26 \pm 0.04$. The ratio of total to nonspecific binding was 9.05 for serous and 10.42 for mucous cells. Specific grains were predominantly associated with the basolateral surfaces of the

Figure 5. Electron micrograph showing the relationship between muscle cells $(M)$ and cholinergic varicosities $(V)$ in the ferret trachealis muscle. Varicosities have free surfaces facing the muscle. $S C$, Schwann cell. Scale bar $=1 \mu \mathrm{m}$. 


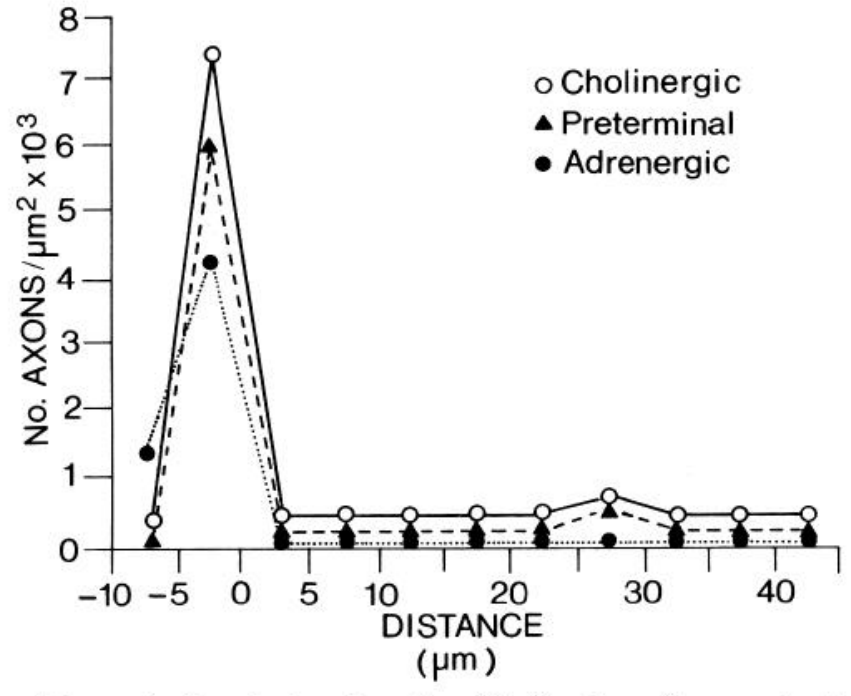

Figure 6. Graph showing the distribution of axons in the vicinity of the trachealis muscle. Distance on the $X$ axis is measured both internal (positive numbers) and external (negative numbers) to the adventitial surface of the muscle. Data represent values pooled from three muscle montages taken from two animals. A total of 45 axons were observed associated with approximately $28,500 \mu \mathrm{m}^{2}$ of smooth muscle.
TABLE III

Relative grain densities after $\left[{ }^{3} \mathrm{H}\right] \operatorname{PrBCM}$ binding for individual cell types

"Total" grain counts reflect uptake in the absence and "Nonspecific" counts reflect uptake in the presence of $10^{-4} \mathrm{M}$ atropine. Grain counts are expressed as number of grains per $100-\mu \mathrm{m}^{2}$ tissue section. Values are means \pm SEM taken from 80 fields in four sections from two blocks of tissue. Absolute grain counts: muscle, total $=2,186$ grains in 19,150 $\mu \mathrm{m}^{2}$, nonspecific $=605$ in $25,250 \mu \mathrm{m}^{2}$; serous cells, total $=4,128$ grains in $221,948 \mu \mathrm{m}^{2}$, nonspecific $=196$ grains in $92,230 \mu \mathrm{m}^{2}$; mucous cells, total $=817$ grains in $48,075 \mu \mathrm{m}^{2}$, nonspecific $=79$ grains in $46,242 \mu \mathrm{m}^{2}$; epithelium, total $=754$ grains in $15,080 \mu \mathrm{m}^{2}$, nonspecific $=206$ grains in $20,600 \mu \mathrm{m}^{2}$.

\begin{tabular}{lcccc}
\hline & Total & Nonspecific & $\begin{array}{c}\text { Total/ } \\
\text { Nonspecific }\end{array}$ & $\begin{array}{c}\text { No. of Receptor } \\
\text { Sites } / \mu \mathrm{m}^{2} \\
\text { Cell Surface }\end{array}$ \\
\hline Muscle & $9.08 \pm 0.65$ & $0.73 \pm 0.38$ & 12.44 & 21 \\
& & & & \\
Gland & & & \\
$\quad$ Serous cells & $3.44 \pm 0.15$ & $0.38 \pm 0.05$ & 9.05 & 5 \\
$\quad$ Mucous cells & $2.71 \pm 0.25$ & $0.26 \pm 0.04$ & 10.42 & 5 \\
Epithelium & $2.27 \pm 0.08$ & $0.13 \pm 0.13$ & 17.46 & 6 \\
\hline
\end{tabular}

gland cells (Fig. 15 and 16). Several sections contained profiles of ciliated (collecting) ducts which, although too few to provide quantitative data, appeared to have less
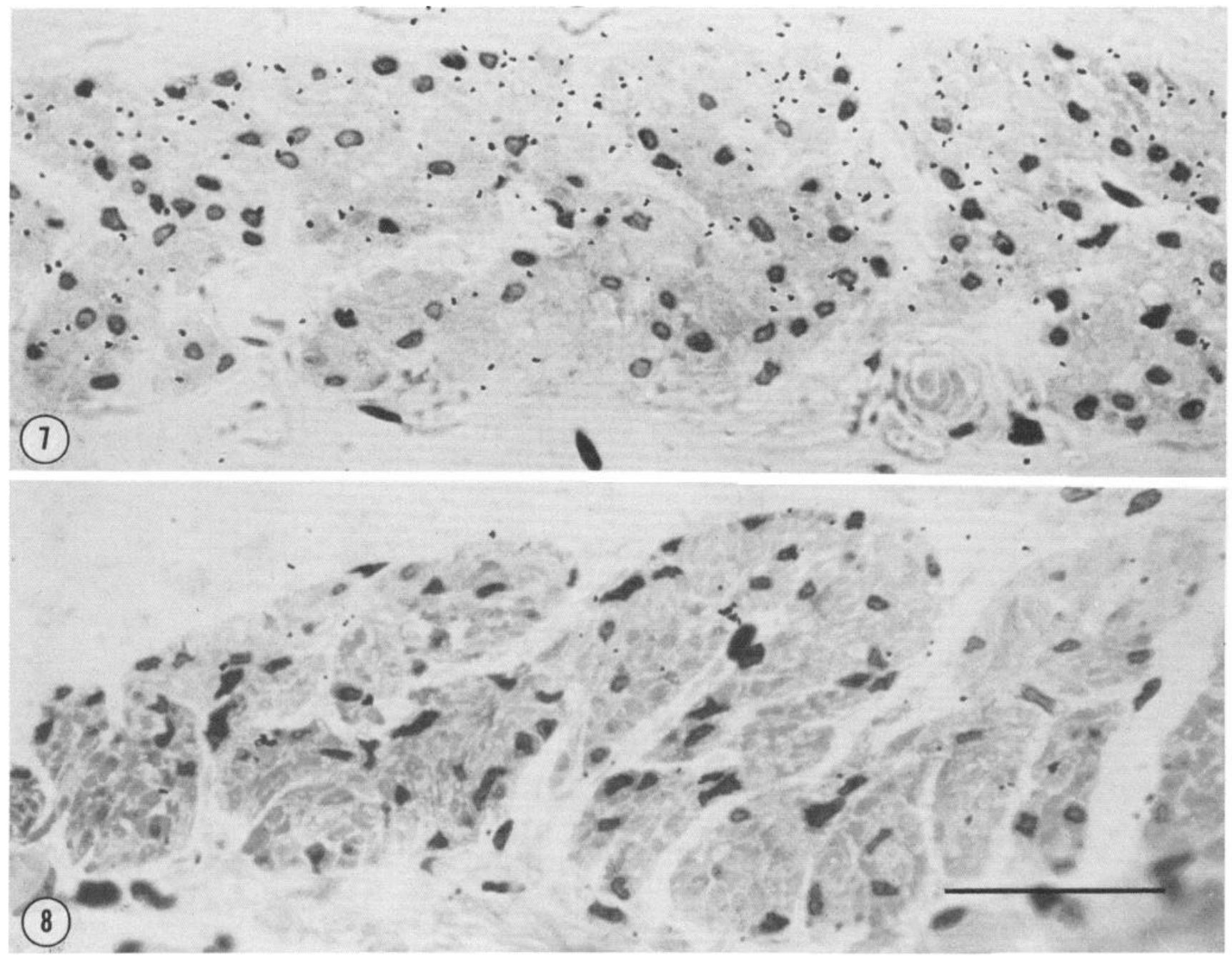

Figure 7. Cross-section through ferret trachealis muscle labeled with $\left[{ }^{3} \mathrm{H}\right] \mathrm{PrBCM}$ in the absence of atropine. Adventitial surface is at the top of the photograph. The scale is as in Figure 8.

Figure 8. Cross-section through ferret trachealis muscle labeled with $\left[{ }^{3} \mathrm{H}\right] \mathrm{PrBCM}$ in the presence of atropine. Adventitial surface is at the top of the photograph. Scale bar $=40 \mu \mathrm{m}$. 

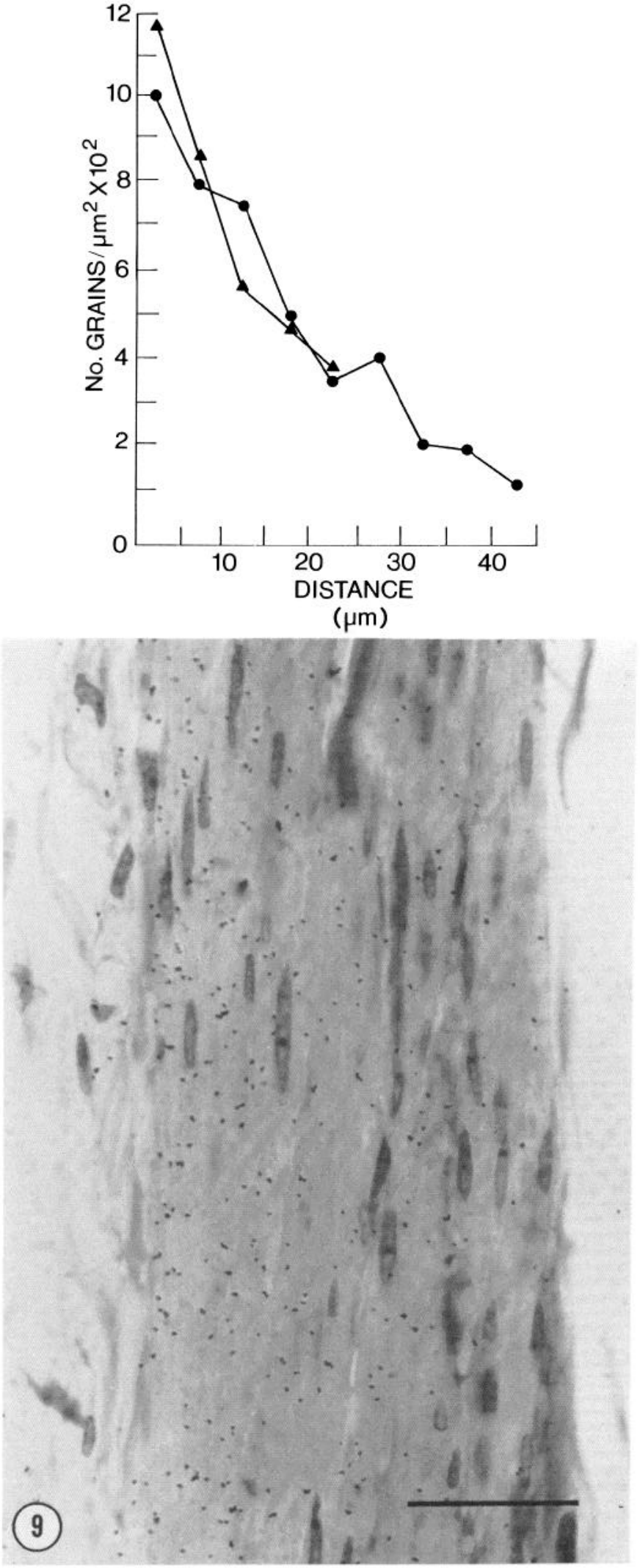

Figure 9. The upper panel is a graph showing the density of autoradiographic silver grains in zones $5 \mu \mathrm{m}$ wide throughout the thickness of the trachealis muscle. The two curves represent values obtained from muscle of $25 \mu \mathrm{m}(\boldsymbol{\Delta})$ and $45 \mu \mathrm{m}(\boldsymbol{O})$ width,

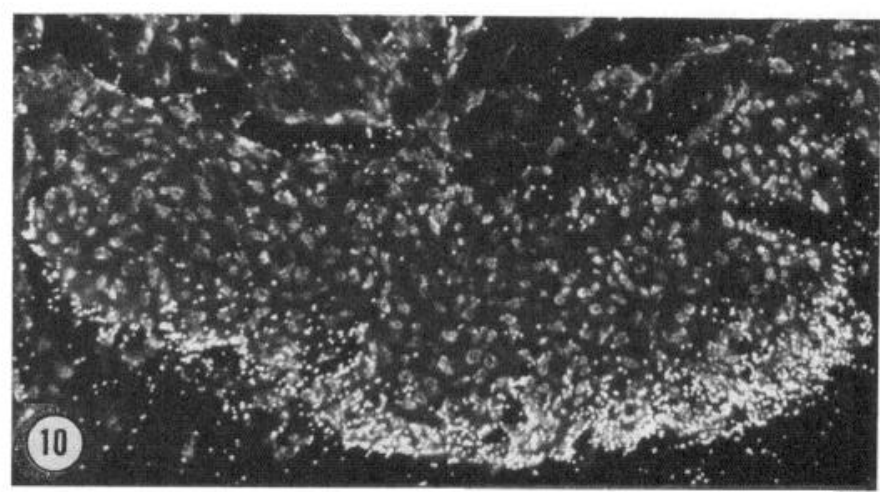

Figure 10. Darkfield micrograph showing distribution of autoradiographic silver grains in trachealis muscle incubated with $\left[{ }^{3} \mathrm{H}\right] \operatorname{PrBCM}$ after the epithelium was stripped away. Binding sites are clustered at the adventitial surface. The scale is as in Figure 11.

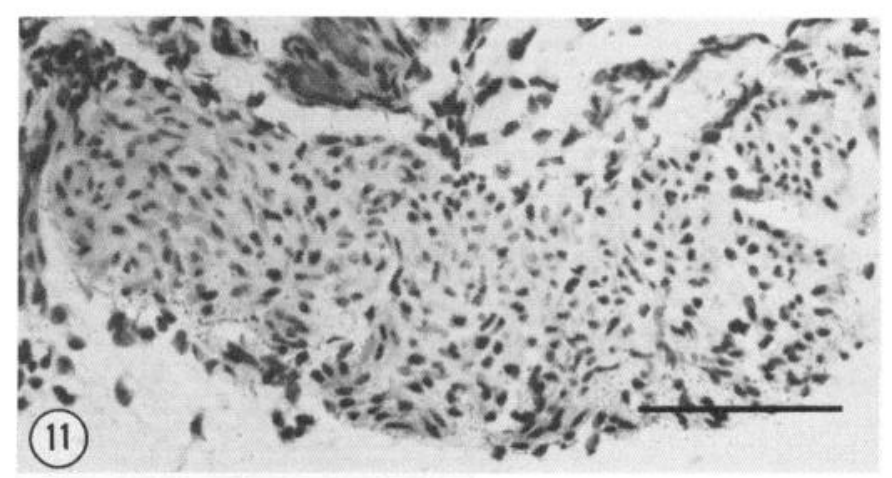

Figure 11. Brightfield micrograph of the same region shown in Figure 10. Scale bar $=60 \mu \mathrm{m}$.

specific labeling than did gland acini. Cholinergic axon varicosities were seen near the ducts, consistent with neural regulation of some aspect of duct function; e.g., ion transport (Marin et al., 1976).

\section{Discussion}

Using autoradiography to determine the pattern of specific binding of the irreversibly binding muscarinic antagonist $\left[{ }^{3} \mathrm{H}\right] \mathrm{PrBCM}$, we have shown that muscarinic receptors occur in smooth muscle, submucosal glands, and epithelium of the ferret trachea.

Although it is impossible with present methods to accurately determine receptor density on the basis of autoradiographic grain counts (Fertuck and Salpeter, 1974; Rogers, 1979), one can derive estimates based on certain assumptions which apply equally to each cell type, making comparative figures reasonably reliable. Based on such estimates, we know the rank order for muscarinic receptor density in the trachea to be muscle $>$ epithelium $\approx$ glands. Furthermore, serous and mucous gland cells contain approximately equal numbers of receptors per unit of cell surface.

respectively. The lower panel is a photograph of a longitudinally sectioned muscle similar to the ones on which grain counts were made. 
TABLE IV

Muscarinic receptors: Density in various tissues

\begin{tabular}{|c|c|c|c|c|c|c|}
\hline Tissue & Species & Ligand & Uptake & $\begin{array}{l}\text { Receptor Density } \\
\left(\text { molecules } / \mu \mathrm{m}^{2}\right)\end{array}$ & Reference & $\begin{array}{l}\text { Assumptions Used } \\
\text { in Calculations }\end{array}$ \\
\hline $\begin{array}{l}\text { Trachea } \\
\text { Muscle } \\
\text { Glands } \\
\text { Epithelium }\end{array}$ & Ferret & PrBCM & $\begin{array}{l}25 \mathrm{pmol} \cdot \mathrm{gm}^{-1} \text { dry } \\
\text { wt }\end{array}$ & $\begin{array}{l}3.6-21 \\
5 \\
6\end{array}$ & This paper & see text \\
\hline Isolated parietal cells & Rat & QNB & 4,900 molecules/cell & 4 & (Ecknauer et al., 1980) & $\mathrm{i}$ \\
\hline $\begin{array}{l}\text { Longitudinal muscle of } \\
\text { small intestine }\end{array}$ & Guinea pig & PrBCM & $\begin{array}{l}150 \mathrm{pmol} / \mathrm{gm} \text { wet } \\
\mathrm{wt}\end{array}$ & 100 & (Burgen et al., 1974) & ii \\
\hline $\begin{array}{l}\text { Longitudinal muscle of } \\
\text { ileum }\end{array}$ & Guinea pig & QNB & $\begin{array}{l}190 \mathrm{pmol} / \mathrm{gm} \text { of tis- } \\
\text { sue }\end{array}$ & 125 & $\begin{array}{l}\text { (Yamamura and Snyder, } \\
1974 \text { ) }\end{array}$ & ii \\
\hline Amnion smooth muscle & Chick & PrBCM & 9 pmol/gm dry wt & 1 & (Cuthbert and Young, 1973) & iii \\
\hline $\begin{array}{l}\text { Cardiac muscle (var- } \\
\text { ious regions) }\end{array}$ & Rabbit & QNB & $\begin{array}{l}\text { 37-302 pmol/gm of } \\
\text { protein }\end{array}$ & $10-90$ & (Fields et al., 1978) & iv \\
\hline $\begin{array}{l}\text { Sternomastoid motor } \\
\text { endplate }\end{array}$ & Mouse & {$\left[{ }^{125} \mathrm{I}\right]$ Bungarotoxin } & & 35,000 & (Fertuck and Salpeter, 1974) & see ref \\
\hline Electroplax & Electrophorus & {$\left[{ }^{125} \mathrm{I}\right]$ Bungarotoxin } & & 33,000 & (Bourgeious et al., 1972) & see ref \\
\hline
\end{tabular}

i. Cells are spheres with the same average volume as mouse parietal cells; i.e., $4,400 \mu \mathrm{m}^{3}$ (Romrell et al., 1975).

ii. Extracellular space $=35 \%$ tissue weight (Prosser, 1974); surface area: volume ratio $=1.4 \mu \mathrm{m}^{2} / \mu \mathrm{m}^{3}($ Gabella, 1979).

iii. Dry weight:wet weight ratio $=0.17$; otherwise same dimensions as guinea pig ileal muscle.

iv. Extracellular space $=20 \%$ tissue weight (Polimeni, 1974); total plasmalemmal surface area:cell volume ratio $=0.5 \mu \mathrm{m}^{2} / \mu \mathrm{m}^{3}($ Somner and Johnson, 1979); dry weight:wet weight ratio $=0.2$ (Randle and Tubbs, 1979); dry weight $=100 \%$ protein.

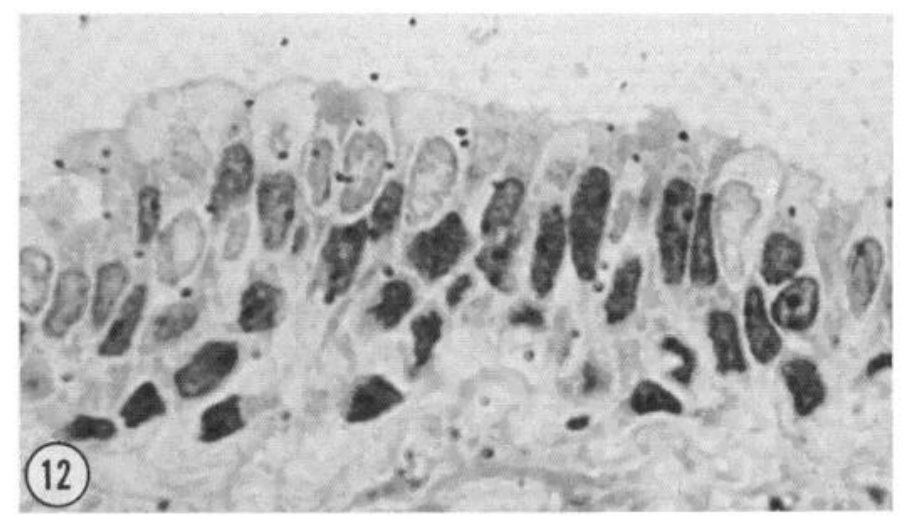

Figure 12. Autoradiograph showing silver grains clustered over ferret tracheal epithelium after incubation with $\left[{ }^{3} \mathrm{H}\right]$ PrBCM in the absence of atropine. The scale is as in Figure 13.

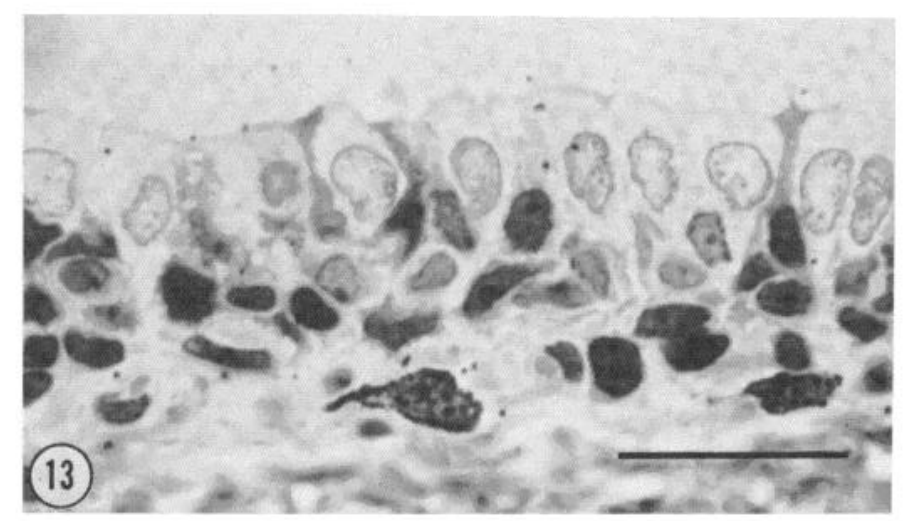

Figure 13. Autoradiograph showing silver grains over ferret tracheal epithelium after incubation with $\left[{ }^{3} \mathrm{H}\right] \mathrm{PrBCM}$ in the presence of atropine. Scale bar $=25 \mu \mathrm{m}$.

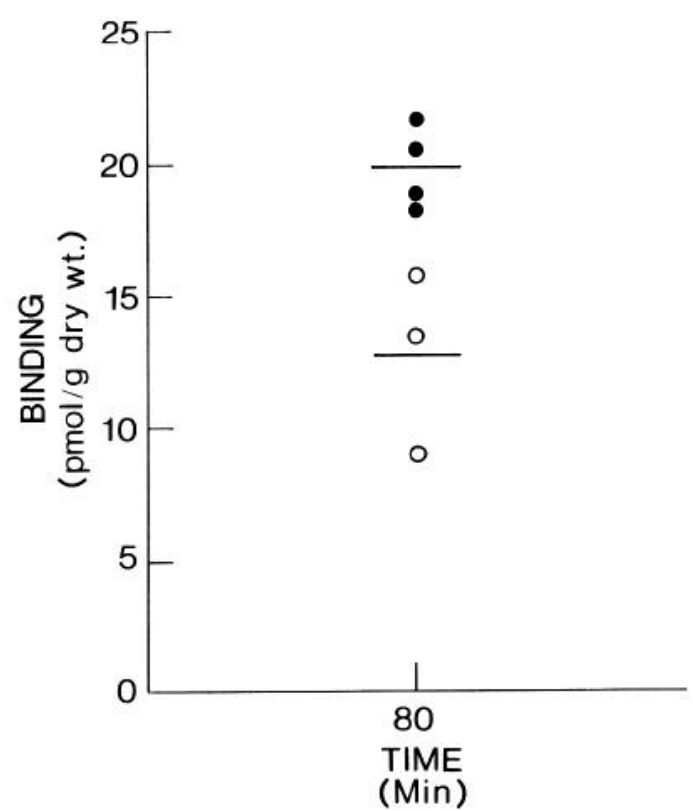

Figure 14. Binding of $\left[{ }^{3} \mathrm{H}\right] \mathrm{PrBCM}$ by epithelial strips in the presence $(\mathrm{O})$ or absence $(-)$ of $10^{-4} \mathrm{M}$ atropine. Horizontal bars show mean values for the two tissue groups. These are statistically different from one another ( $p<0.02$, Student's $t$ test).

Distribution patterns of muscarinic receptors. The most interesting aspect of $\left[{ }^{3} \mathrm{H}\right] \mathrm{PrBCM}$ labeling in the muscle was the nonuniform distribution of autoradiographic grains; i.e., the outer layers of muscle cells were 3 to 10 times as densely labeled as the inner layers. Although it is possible that, due to insufficient penetration of $\left[{ }^{3} \mathrm{H}\right]$ PrBCM to inner layers of muscle, this distribution was produced artifactually, two findings give confidence that the receptor gradient is real. First, surgically stripping the epithelial surface prior to incubation of the muscle 

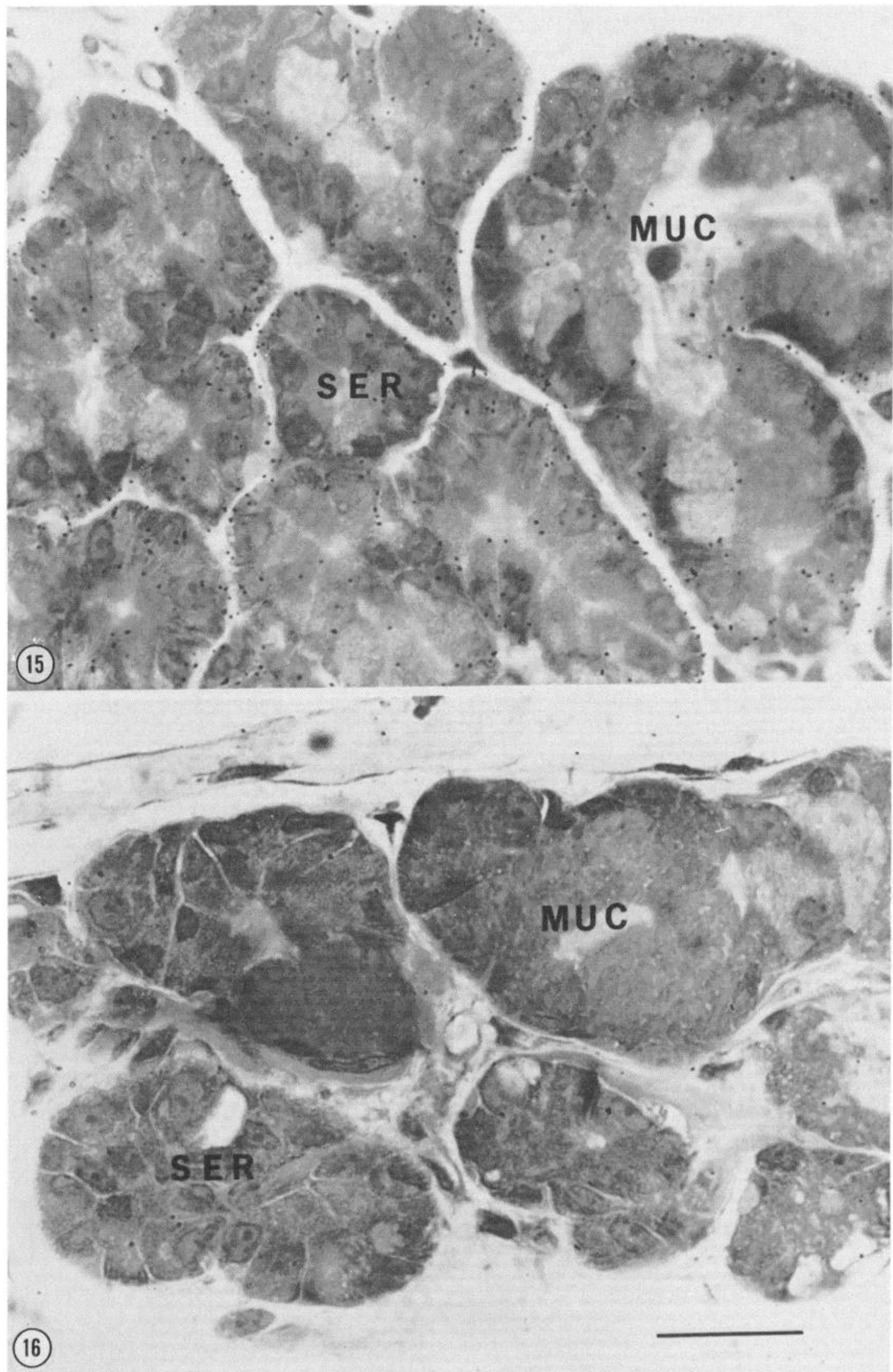

Figure 15. Autoradiograph of ferret tracheal glands incubated with $\left[{ }^{3} \mathrm{H}\right] \operatorname{PrBCM}$. SER, serous; $M U C$, mucous. Note basolateral labeling where membrane is orthogonal to section plane. The scale is as in Figure 16.

Figure 16. Ferret tracheal glands incubated with $\left[{ }^{3} \mathrm{H}\right] \mathrm{PrBCM}$ in the presence of atropine $\left(10^{-4} \mathrm{M}\right)$. Scale bar $=25 \mu \mathrm{m}$. Abbreviations are as in Figure 15. 
with $\left[{ }^{3} \mathrm{H}\right] \operatorname{PrBCM}$ did not change either the pattern of autoradiographic labeling or the number of specific counts in the muscle. Second, the distribution of cholinergic varicosities paralleled the distribution of PrBCMbinding sites. In effect, this distribution is predictable since the numerous gap junctions connecting smooth muscle cells probably reduce the requirement for either axons or receptors in the inner muscle. Electrophysiological determinations of space constants many times the cell length have indeed demonstrated electrophysiological coupling between smooth muscle cells of the trachealis in other species (Suzuki et al., 1976).

In the glands, a different distribution pattern for both axons and receptors was observed. In the gland region, cholinergic axons are dispersed homogeneously throughout the interstitium at relatively low density, occurring near serous and mucous cells with equal frequency (Murlas et al., 1980). Thus, acetylcholine diffuses from interstitium to gland, having good access to basolateral but not apical cell membranes (due to larger diffusion distances and apical tight junctions connecting adjacent cells). Consistent with this, receptor concentration was high over basolateral, and low or nonexistent over apical, cell membranes. Within the epithelium, cholinergic axons occur near the basement membrane, in some species contacting the basolateral membranes of the epithelial cells (Jeffery and Reid, 1973). Receptor distribution in epithelium, although not as clear cut, also showed receptors to be most concentrated basolaterally, with apical membranes generally free of silver grains. Thus, receptors can, in general, be described as being most concentrated in tissue or cellular regions facing the innervation. This suggests that autonomic axons may play a role in the genesis and/or maintenance of receptor distribution on effector cells. This possibility could be examined with regard to changes in receptor distribution occurring during development or following denervation.

Role of muscarinic receptors in glands. The finding of muscarinic receptors on both serous and mucous cells confirms the capacity of both cell types to contribute to the secretory response of tracheal glands to vagal or cholinomimetic stimulation. The secretory response has been documented in many species, including ferret, using radiolabeled mucin precursors (Sturgess and Reid, 1972; Chakrin et al., 1973; Boat and Kleinerman, 1975; Gallagher et al., 1975), microcollection methods (Quinton, 1979; Ueki et al., 1980), the hillock method (Davis et al., 1979; Borson et al., 1980), and a variety of earlier techniques (e.g., Florey et al., 1932). Because of the difficulties in isolating and separating serous and mucous cells from the trachea, direct radioligand-binding assays on cell homogenates have not yet been possible. Degranulation of serous cells in response to cholinomimetics has been documented morphometrically (Basbaum et al., 1981), but the response is more difficult to establish for mucous cells by the same methods. Therefore, autoradiography currently represents the only technique by which characterization of receptors on both serous and mucous cells can be achieved.

Role of muscarinic receptors in trachealis muscle. Consistent with the well established excitatory effects of vagal or cholinomimetic stimulation on contraction of airway muscle in dog, cat (Cabezas et al., 1971; Nadel et al., 1971; Hahn et al., 1976), and ferret (Skoogh et al., 1983), the trachealis muscle was heavily labeled by $\left[{ }^{3} \mathrm{H}\right]$ PrBCM.

The ferret trachealis is similar to airway smooth muscle of other species (Cameron and Kirkpatrick, 1977; Hoyes and Barber, 1980; Knight et al., 1981) in having a sparse innervation, but may be somewhat unusual in its asymmetric distribution of axons. In general, the ferret trachealis resembles a single unit smooth muscle, with excitation apparently emanating from adventitially placed neuromuscular contacts and propagating throughout the muscle via gap junctions. This arrangement is similar to that described in dog trachealis (Kannan and Daniel, 1980) and may be optimal for obtaining rapid synchronous contraction throughout the muscle during cough.

Role of muscarinic receptors in epithelium. The finding of muscarinic receptors in tracheal epithelium is consistent with observations that cholinergic agents have small but significant effects on active ion transport across dog tracheal epithelium (Marin et al., 1976) and potent stimulatory effects on ciliary beat frequency (van As and Avner, 1982). Recently, D. L. Coleman (personal communication) has found $10^{-4} \mathrm{M}$ methacholine to increase the potential difference and short-circuit current across ferret tracheal epithelium from 3.5 to $6.0 \mathrm{mV}$ and from 0.17 to $0.28 \mu \mathrm{Eq} \cdot \mathrm{cm}^{-2} \cdot \mathrm{hr}^{-1}$ (means from two tissues from the same animal).

Receptor density estimates. Muscarinic receptor density was calculated from both binding assays and autoradiographic grain counts. Because of the assumptions associated with these calculations we judge the error associated with the autoradiographic calculations to be in the neighborhood of 3- to 5 -fold. The estimates we obtained by scintillation counting were approximately 5 fold lower than similar estimates by autoradiography. The values for nonspecific binding vary greatly using biochemical versus autoradiographic methods. This is probably attributable to the fact that nonspecific binding was assessed biochemically using tissue pieces containing significant amounts of connective tissue; i.e., a large source of nonspecific binding. In contrast, nonspecific binding was assessed autoradiographically only over gland, muscle, and epithelial cells. If the biochemical measurements could have been made on purified, isolated cells, nonspecific binding would have been significantly reduced and comparable to values found using autoradiography.

It is possible that caveolae present on smooth muscle surfaces contain muscarinic receptors and are responsible for a portion of the $\left[{ }^{3} \mathrm{H}\right] \mathrm{PrBCM}$ binding. Techniques needed to determine this are beyond the scope of the present work. We did not include the caveolae in our estimates of surface area in smooth muscle cells. If caveolae do contain $\left[{ }^{3} \mathrm{H}\right] \mathrm{PrBCM}$-binding sites, our receptor density values for smooth muscle membrane represent overestimates. Similarly, our receptor density values (per square micrometer cell surface area) could be overestimates if a significant number of binding sites occur intracellularly. This seems unlikely from observation of grain distribution in cross-sections of muscle and gland cells (Figs. 7 and 15).

Comparison with other receptors. Other work done in 
this laboratory (Barnes and Basbaum, 1983) has shown significant overlap in the distribution of $\alpha$ - and $\beta$-receptors in serial frozen sections from the ferret trachea. From the degree of overlap, it seems likely that serous and mucous cells possess more than one, and possibly several types of receptor. This is consistent with the finding that tracheal serous cells secrete in response to both $\alpha$-adrenergic and cholinergic stimulation (Basbaum et al., 1981; Tom-Moy et al., 1983). Multiple receptors mediating secretion from a single cell type have previously been demonstrated in the rat parotid (Schramm and Selinger, 1974).

We compared our receptor density estimates with similar estimates made for muscarinic receptors in other tissues, and also with estimates made for nicotinic receptors at the skeletal neuromuscular junction (Table IV). Although our estimates fall well within the range of densities reported for other tissues containing muscarinic receptors, they are considerably lower than estimates of muscarinic receptor density in intestinal smooth muscle (20 versus 100 receptors $/ \mu \mathrm{m}^{2}$ ) (Burgen et al., 1974; Yamamura and Snyder, 1974). Our figure for the trachealis muscle, however, is an average computed throughout the muscle thickness. If the density at the outer surface only were computed, it would be severalfold higher (see Fig. 9 ), bringing it close to the figure computed for intestinal smooth muscle. The figures for all muscarinic receptors so far examined are significantly smaller than those reported for nicotinic receptors $\left(\sim 33,000 / \mu \mathrm{m}^{2}\right)$ at the skeletal neuromuscular (Fertuck and Salpeter, 1974) and electrophorous electroplax (Bourgeious et al., 1972) junctions. Of some interest is the fact that extrajunctional nicotinic receptors in skeletal muscle show a density (Hartzell and Fambrough, 1972) similar to that found for muscarinic receptors in smooth muscle.

In conclusion, we have localized muscarinic receptors in the glands, muscle, and epithelium of the trachea. To our knowledge it is the first description of autonomic receptor distribution in mammalian smooth muscle, exocrine glands, or epithelium. Previous studies have mapped muscarinic receptors in both frog heart (Hartzell, 1980) and avian salt gland (Hootman, 1982). The use of autoradiography uncovered several basic facts that could not have been learned by binding assays performed on homogenates of the tissue. First, serous and mucous gland cells contain approximately equal numbers of muscarinic receptors and thus (innervation being constant (Murlas et al., 1980)) may contribute equally to the secretory response induced by cholinergic stimulation. Second, receptors on the gland and epithelial cells are concentrated basolaterally, facing the innervation. Third, receptors on trachealis muscle are several times more numerous in outer than inner layers of the muscle. The receptor distribution consistently coincides with that of cholinergic axons, although no evidence for receptor "hot spots" immediately apposed to axons was found. This is consistent with observations made by intracellular recording from cultured mammalian smooth muscle cells following iontophoretic application of acetylcholine (Purves, 1974). In future studies, it will be interesting to determine whether smooth muscles having different innervation patterns (e.g., sphincter pupillae (Gabella, 1974)) reveal correspondingly different recep- tor distributions. The particular arrangement of axons, receptors, and gap junctions found in the trachealis muscle may have evolved to provide the rapid, synchronous contraction this muscle achieves during the physiologically adaptive cough reflex; the arrangement in other muscles may be found to vary with the specific function of each muscle.

\section{References}

Barnes, P. J., and C. B. Basbaum (1983) Mapping of adrenergic receptors in the trachea by autoradiography. Exp. Lung Res., 5: $183-192$.

Bashaum, C.B., I. Ueki, L. Brezina, and J. A. Nadel (1981) Tracheal submucosal gland serous cells stimulated in vitro with adrenergic and cholinergic agonists: a morphometric study. Cell Tissue Res. 220: 481-498.

Boat, T. F., and J. I. Kleinerman (1975) Human respiratory tract secretions. II. Effect of cholinergic and adrenergic agents on in vitro release of protein and mucous glycoprotein. Chest 67: 32S-34S.

Borson, D. B., R. A. Chinn, B. Davis, and J. A. Nadel (1980) Adrenergic and cholinergic nerves mediate fluid secretion from tracheal glands of ferrets. J. Appl. Physiol. 49: 10271031.

Bourgeious, J. P., A. Ryter, A. Menez, G. Fromagent, P. Bogquet, and J. P. Changeux (1972) Localization of the cholinergic receptor protein in Electrophorus electroplax by high resolution autoradiography. FEBS Lett. 25: 217-232.

Breeze, R. G., and E. B. Wheeldon (1977) The cells of the pulmonary airways. Am. Rev. Respir. Dis. 116: 705-777.

Burgen, A. S. V., C. R. Hiley, and J. M. Young (1971) The binding of $\left[{ }^{3} \mathrm{H}\right]$ propylbenzilylcholine mustard by longitudinal muscle strips from guinea-pig small intestine. Br. J. Pharmacol. 50: 145-151.

Cabezas, G. A., P. D. Graf, and J. A. Nadel (1971) Sympathetic versus parasympathetic nervous regulation of airways in dogs. J. Appl. Physiol. 31: 651-655.

Cameron, A. C., and T. C. Kirkpatrick (1977) A study of excitatory neuromuscular transmission in the bovine trachea. J. Physiol. (Lond.) 270: 733-745.

Chakrin, L. W., A. P. Baker, P. Christian, and J. R. Wardell, Jr. (1973) Effect of cholinergic stimulation on the release of macromolecules by canine trachea in vitro. Am. Rev. Respir. Dis. 108: 69-76.

Cuthbert, A. W., and J. M. Young (1973) Determination of the number of muscarinic receptors in chick amnion muscle. $\mathrm{Br}$. J. Pharmacol. 47: 631-632P.

Dale, H. H. (1914) The action of certain esters and ethers of choline and their relation to muscarine. J. Pharmacol. Exp. Ther. 6: 147-190.

Davis, B., R. Chinn, P. Graf, D. Popovac, and J. Nadel (1979) Effect of phenylephrine and superior laryngeal nerve stimulation on submucosal gland secretion in canine trachea in vivo. Clin. Res. 27: 55A.

Ecknauer, R., W. J. Thompson, L. R. Johnson, and G. C. Rosenfeld (1980) Isolated parietal cells: $\left[{ }^{3} \mathrm{H}\right] \mathrm{QNB}$ binding to putative cholinergic receptors. Am. J. Physiol. 239: G204G209.

Fertuck, H. C., M. M. Salpeter (1974) Localization of acetylcholine receptor by ${ }^{125}$ I-labelled alpha bungarotoxin binding at mouse motor endplates. Proc. Natl. Acad. Sci. U. S. A. 71: 1376-1378.

Fields, J. Z., W. R. Roseke, E. Morkin, and H. I. Yamamura (1978) Cardiac muscarinic receptors: Biochemical identification and characterization. J. Biol. Chem. 253: 3251-3258.

Florey, H., H. M. Carleton, and A. Q. Wells (1932) Mucus secretion in the trachea. Br. J. Exp. Pathol. 13: 269-284.

Gabella, G. (1974) The sphincter pupillae of the guinea pig: 
Structure of muscle cells, intercellular relations and density of innervation. Proc. R. Soc. Lond. (Biol.) 186: 369-386.

Gabella, G. (1979) Hypertrophic smooth muscles. I. Size and shape of cells, occurrence of mitoses. Cell Tissue Res. 201: 63-78.

Gallagher, J. T., P. W. Kent, M. Passatore, R. J. Phipps, and P. S. Richardson (1975) The composition of tracheal mucus and the nervous control of its secretion in the cat. Proc. $R$. Soc. Lond. (Biol.) 192: 49-76.

Gill, E. W., and H. P. Rang (1966) An alkylating derivative of benzilylcholine with specific and long-lasting parasympatholytic activity. Mol. Pharmacol. 2: 284-297.

Hahn, H. L., P. D. Graf, and J. A. Nadel (1976) Effect of vagal tone on airway diameters and on lung volume in anesthetized dogs. J. Appl. Physiol. 41: 581-589.

Hartzell, H. C. (1980) Distribution of muscarinic acetylcholine receptors and presynaptic nerve terminals in amphibia heart. J. Cell Biol. 86: 6-20.

Hartzell, H. C., and D. M. Fambrough (1972) ACh receptors. Distribution and extrajunctional density in rat diaphragm after denervation correlated with ACh sensitivity. J. Gen. Physiol. 60: 248-262.

Hootman, S. (1982) ${ }^{3} \mathrm{H}-$ QNB binding to muscarinic receptors in intact avian salt gland cells. Am. J. Physiol. 243: C254C261.

Hoyes, A. D., and P. Barber (1980) Innervation of the trachealis muscle in the guinea pig: A quantitative ultrastructural study. J. Anat. 130: 789-800.

Jacob, S., and S. Poddar (1982) Mucous cells of the tracheobronchial tree in the ferret. Histochemistry 73: 599-605.

Jeffery, P., and L. Reid (1973) Intra-epithelial nerves in normal rat airways: A quantitative electron microscopic study. J. Anat. 114: 35-45.

Kannan, M. S., and E. E. Daniel (1980) Structural and functional study of control of canine tracheal smooth muscle. Am. J. Physiol. 238: C27-C33.

Knight, D. S., A. L. Hyman, and P. J. Kadowitz (1981) Innervation of intrapulmonary airway smooth muscle of the dog, monkey and baboon. J. Auton. Nerv. Syst. 3: 31-43.

Kuhar, M. J., N. Taylor, J. K. Wamsley, E. C. Hulme, and N. J. M. Birdsall (1981) Muscarinic cholinergic receptor localization in brain by electron microscopic autoradiography. Brain Res. 216: 1-9.

Lane, M. A., A. Sastre, M. Law, and M. M. Salpeter (1977) Cholinergic and adrenergic receptors on mouse cardiocytes in vitro. Dev. Biol. 57: 254-269.

Lentz, T. L., J. E. Mazurkiewicz, and J. Rosenthal (1977) Cytochemical localization of acetylcholine receptors at the neuromuscular junction by means of HRP-labelled alphabungarotoxin. Brain Res. 132: 423-442.

Marin, M. G., B. Davis, and J. A. Nadel (1976) Effect of acetylcholine on $\mathrm{Cl}^{-}$and $\mathrm{Na}^{+}$fluxes across dog tracheal epithelium in vitro. Am. J. Physiol. 231: 1516-1549.

Marshall, L. M. (1981) Synaptic localization of alpha-bungarotoxin binding which blocks nicotinic transmission at frog sympathetic neurons. Proc. Natl. Acad. Sci. U. S. A. 78: 3014-3018.

Murlas, C., J. A. Nadel, C. B. Basbaum (1980) A morphometric analysis of the autonomic innervation of cat tracheal glands. J. Auton. Nerv. Syst. 2: 23-37.

Murlas, C., J. A. Nadel, and J. M. Roberts (1982) The muscarinic receptors of airway smooth muscle: their characterization in vitro. J. Appl. Physiol. 52: 1084-1091.

Nadel, J. A., G. A. Cabezas, and J. H. M. Austin (1971) In vivo roentgenographic examination of parasympathetic innerva- tion of small airways: Use of powdered tantalum and a fine focal spot x-ray tube. Invest. Radiol. 6: 9-17.

Polimeni, P. I. (1974) Extracellular space and ionic distribution in rat ventricle. Am. J. Physiol. 227: 676-683.

Prosser, C. L. (1974) Smooth muscle. Annu. Rev. Physiol. 36: 503-535.

Purves, R. D. (1974) Muscarinic excitation: A microelectrophoretic study on cultured smooth muscle cells. Br. J. Pharmacol. 52: 77-86.

Quinton, P. M. (1979) Composition and control of secretions from tracheal bronchial submucosal glands. Nature 279: 551552.

Randle, P. J., and P. K. Tubbs (1979) Carbohydrate and fatty acid metabolism. In Handbook of Physiology. Section 2: The Cardiovascular System. Vol. 1: The Heart, R. M. Berne, and N. Sperelakis, eds., pp. 805-844, American Physiological Society, Bethesda, MD.

Rogers, A. W. (1979) 'Techniques of Autoradiography, Elsevier/ North-Holland Biomedical Press, New York.

Romrell, L. J., M. R. Coppe, D. R. Munro, and S. Ito (1975) Isolation and separation of highly enriched fractions of viable mouse gastric parietal cells by velocity sedimentation. J. Cell. Biol. 65: 428-438.

Rotter, A., N. J. M. Birdsall, A. S. V. Burgen, P. M. Field, E. C. Hulme, and G. Raisman (1979) Muscarinic receptors in the central nervous system of the rat. I. Technique for autoradiographic localization of the binding of $\left[{ }^{3} \mathrm{H}\right]$ propylbenzilylcholine mustard and its distribution in the forebrain. Brain Res. Rev. 1: 141-165.

Schramm, M., and Z. Selinger (1974) The function of alpha and beta adrenergic receptors and a cholinergic receptor in the secretory cell of rat parotid gland. In Advances in Cytopharmacology, B. Ceccarelli, F. Clementi, and J. Meldolesi, eds., p. 29, Raven Press, New York.

Skoogh, B.-E., M. Grillo, and J. A. Nadel (1983) Neutral red stains ganglia in the vagal motor pathway to ferret trachea without affecting ganglionic transmission. J. Neurosci. Methods. 8: 33-39.

Somner, J. R., and E. A. Johnson (1979) Ultrastructure of cardiac muscle. In Handbook of Physiology. Section 2: The Cardiovascular System. Vol. 1: The Heart, R. M. Berne, and N. Sperelakis, eds., pp. 113-186, American Physiological Society, Bethesda, MD.

Sturgess, J., and L. Reid (1972) An organ culture study of the effect of drugs on the secretory activity of the human bronchial submucosal gland. Clin. Sci. 43: 533-543.

Suzuki, H., K. Morita, and H. Kuriyama (1976) Innervation and properties of the smooth muscle of the dog trachea. Jpn. J. Physiol. 26: 303-320.

Tom-Moy, M., C. Basbaum, and J. A. Nadel (1983) Localization and release of lysozyme from ferret trachea: Effects of adrenergic and cholinergic drugs. Cell Tissue Res. 228: 549-562.

Ueki, I., V. German, and J. Nadel (1979) Direct measurement of tracheal mucous gland secretion with micropipettes in cats: Effects of cholinergic and alpha-adrenergic stimulation. Clin. Res. 27: 59a.

Ueki, I., V. German, and J. Nadel (1980) Micropipette measurement of airway submucosal gland secretion: Autonomic effects. Am. Rev. Respir. Dis. 121: 351-357.

van As, A., and B. P. Avner (1982) Autonomic control of ciliary beat frequency. Am. Rev. Respir. Dis. 125: 159.

Yamamura, H. I., and S. H. Snyder (1974) Muscarinic cholinergic receptor binding in the longitudinal muscle of the guinea pig ileum with $\left[{ }^{3} \mathrm{H}\right]$ quinuclidinyl benzilate. Mol. Pharmacol. 10: 861-867. 